\title{
FROM PSB TO PRIVATISATION
}

\section{STRUCTURES AND VULNERABILITIES OF THE GREEK-CYPRIOT BROADCASTING SECTOR}

\author{
Theodora A. Maniou \\ Department of Journalism, Frederick University \\ 7, Y.Frederickou str., 1036, Nicosia \\ Cyprus \\ t.maniou@frederick.ac.cy
}

\begin{abstract}
Around the world, the historical evolution of television follows every country's history and is closely related to the structures of every society within which it operates. In Cyprus, broadcasting remained under the direct control of the state for more than thirty years while significant political events can be associated with changes in the audiovisual media landscape. Public service broadcasting (PSB) television was established in 1957, only three years before the country denounced British colonialism and became an independent Republic, under the auspices and guidance of the BBC. For thirty-five years, the one and only PSB television channel was predominating the country's broadcasting sector and it was only in 1992 that private television channels were allowed to operate. As expected, broadcasting suffered a series of political demerits that left narrow margins for growth and technological development. This article presents a historical overview of the evolution of television in the country in accordance to the specific historical artefacts that took place and generated a series of disadvantages still reflecting upon the Cypriot private broadcasting sector. The aim of the article is to present the interrelation between private broadcasting and politics and its current aftermath in Cyprus. Through a comparative analysis of different surveys (conducted after 2000) depicting the audience's points of view regarding private and PSB television, this study highlights the specific characteristics, structures and vulnerabilities of the current broadcasting sector in Cyprus.
\end{abstract}

Keywords: Television, Cyprus, Private Channels, Public Service Broadcasting, Broadcasting Sector, Commercial Channels, Audiovisual Media

\section{Introduction}

All around Europe, the historical evolution of television (initially as Public Service Broadcasting organisations) seems to have followed similar patterns of development regarding the introduction of the medium, moving from Public Service Broadcasting (PSB) to the commercialisation of the audiovisual sector. However, in regards to regulation, small states 
tended to adopt a more interventionist approach, while their evolutionary perspective was directly or indirectly affected by their political traditions ${ }^{1}$.

In terms of funding the operation of the newly formed medium, with the exemption of Britain and the BBC, it was based upon three basic models: a public administration, either directly funded by the state plus a small advertising revenue (e.g., Cyprus, Greece) or advertising revenue (e.g., Spain) or a combination of both ${ }^{2}$. In this perspective, the structure of each European PSB remains a subsidiarity principle, whereby each member state has the power to organise its PSB as it sees fit ${ }^{3}$.

As expected, the newly formed medium after the 1950s largely attracted governmental and wider political attention around Europe, while reflecting historical and political artefacts. For example, in Cyprus and Greece - two similarly polarized pluralist countries ${ }^{4}$ - broadcasting remained under the direct control of the state for more than thirty years and significant political events can be associated with changes in the media landscape ${ }^{5}$.

This article presents a historical overview of the evolution of television in the Republic of Cyprus, focussing mainly on private channels, in accordance to the specific historical artefacts that took place and generated a series of disadvantages still reflecting upon the Cypriot private broadcasting sector. The aim of this article is to present the relation between private broadcasting and politics and its current aftermath in Cyprus. Specifically, the research is focussed on the period after 2000; through a comparative study of different surveys (conducted in 2010, 2015 and 2016) depicting both the audience point of views and the news content of private television channels, this work aims to highlight the specific characteristics and structures of the current private broadcasting sector in the country.

\section{The Evolution of the Cypriot Television: Features and Characteristics}

Public service television in Cyprus was established in 1957, only three years before the country denounced British colonialism and became an independent Republic, under the auspices and guidance of the BBC. In 1959, the Cyprus Broadcasting Service ceased to be a governmental department and was renamed the Cyprus Broadcasting Corporation under the Cyprus Broadcasting Corporation Act 300A . For thirty five years the public channel RIK (CyBC) was predominating the country's broadcasting sector and it was only in 1992 that private television channels were allowed to operate, under the auspices of the Law 29 (1) 1992. At the same time, RIK2 (CyBC 2), the second channel of public service broadcasting was created, focussed mainly on entertainment content, while the burden of informational programmes relied heavily on RIK1 (CyBC 1)7.

Broadcasting in Cyprus suffered a series of political demerits, such as clientelism, bureaucracy and governmentcentred administration - depicting in fact the precise entities of the country's political system, which left narrow margins for growth and technological development ${ }^{8}$. At the same time, although CyBC broadcasted programmes in all three official languages of the country (Greek, Turkish and English) since its early days, it failed to develop a

\footnotetext{
1 Manuel Puppis, Leen d' Haenens, Thomas Steinmauer and Matias Kunzler, 'The European and Global Dimension: Taking Small Media Systems Research to the next level', The International Communication Gazette, 7, 1-2, 2009, 105-112 (DOI:10.1177/1748048508097936).

2 Jerome Bourdon, 'A History of European Television News: From Television to Journalism, and Back?', Communications, $25,1,2000,61-84$.

3 Nicholas Nicholi, 'The role of Public Service Broadcasting in Cyprus during a Time of Austerity', The Cyprus Review, 26,1 , Spring $2014,206$.

4 Manuel Puppis et al., 'The European and Global Dimension: Taking Small Media Systems Research to the next level', 2009.

5 Christoforos Cristoforou, 'Greek Cypriot media development and Politics', The Cyprus Review, 22 February $2010,235-245$.

6 Source: http://www.hellenicaworld.com/Cyprus/TVRadio/en/CyprusBroadcastingCorporation.html

7 Source: http://www.riknews.com.cy/index.php/rik-corporate/history

8 Theodora Maniou, Television, Society and Political News: A Theoretical and Empirical Approach to the Cypriot Public Sphere (in Greek),

Epikentro Publications, 2013
} 
Table 1. Trust and reliability for CyBC in 2010

\begin{tabular}{lccc}
\hline & Total Population & Women & Men \\
\hline $\begin{array}{l}\text { I think RIK is trustworthy and } \\
\text { reliable }\end{array}$ & $40 \%$ & $40.75 \%$ & $40 \%$ \\
$\begin{array}{l}\text { I think RIK is NOT trustworthy } \\
\text { and reliable }\end{array}$ & $48 \%$ & $48 \%$ & $48.9 \%$ \\
No opinion & $12 \%$ & $11.25 \%$ & $11.1 \%$ \\
\hline Total & $100 \%$ & $100 \%$ & $100 \%$ \\
\hline
\end{tabular}

Table 2. Trust and Reliability for CyBC from 2010 to 2016.

\begin{tabular}{lcc}
\hline & Total Population in 2010 & Total Population in 2016 \\
\hline I think RIK is trustworthy and reliable & $40 \%$ & $\mathbf{2 1 \%}$ \\
I think RIK is NOT trustworthy and reliable & $48 \%$ & $\mathbf{7 0 \%}$ \\
No opinion & $12 \%$ & $9 \%$ \\
& & $100 \%$ \\
\hline Total & $100 \%$ & $100 \%$ \\
\hline
\end{tabular}

bi-communal character, especially after the Turkish military invasion of 1974. On the other hand, the traditional GreekCypriot identity (as well as the Turkish-Cypriot one) - depicted through television - was and still is faced with a bicommunal problem and a military invasion in the country ${ }^{9}$. Besides, in a multicultural environment, such as the Cypriot one, the establishment and development of a public broadcasting corporation is not purely a technological or political issue, but has broader social and cultural dimensions, since the representation of all existing cultural, ethnic and/or religious identities is essential for the corporation by all parts of the society ${ }^{10}$.

Although $C y B C$ ceased to exist as a governmental department as early as 1959, the government entirely controls the organisation today, both in terms of finance and administration: CyBC's budget relies heavily on the country's budget and its yearly allowance is a matter of parliamentary discussion and decision. Moreover, the government in office directly appoints the organisation's administration while journalists and other employees enjoy the status of public servants, with minor exceptions that work under long term contracts ${ }^{11}$. As expected, $C y B C$ relies heavily upon the government in office for each and every decision that needs to be made, either in the short or in the long term.

As a result, public opinion in Cyprus is under the impression that historically, $C y B C$ serves the interests of the political party in office, while - as a survey of 2010 has shown - the vast majority of the audience does not trust the media ${ }^{12}$ :

Recent measurements show that negative feelings concerning trust and reliability towards $C y B C$ have risen in recent years. As the Eurobarometer survey for Cyprus (Fall 2016) ${ }^{13}$ has shown (see second column of Table 2), there seems to be a huge increase concerning feelings of distrust.

9 Naya Roussou, 'Television, Cultural Identity and Youth Lifestyles in Cyprus: Secure Moorings in a Shifting World?', European Journal of Communication, 17, 3, 2002, 365.

10 Nikolaos Stelyya, ‘The Stort-lived Bi-communal Cyprus Broadcasting Corporation', Media History, 22 February 2016, 217-231 (DOI:10.180/1368 8804.2016.1161502).

11 Chrysanthos Chrysanthou, Mass Media: Martyrs and lead actors (in Greek), Armida publications, 2008, p.143.

12 Theodora Maniou, Television, Society and Political News: A Theoretical and Empirical Approach to the Cypriot Public Sphere, 2013, 127-129.

13 Source: http://ec.europa.eu/COMMFrontOffice/publicopinion/index.cfm/Survey/getSurveyDetail/instruments/SPECIAL/surveyKy/2119 


\section{The Development of Private Broadcasting}

The Cypriot broadcasting sector was rapidly altered after 1990. Commercial broadcasting was introduced as a result of pressure by social forces and local authorities as well as the general climate in regard to changes in European media policies ${ }^{14}$. To begin with, while the Law 29 (1) 1992 allowed the introduction of private television channels, it failed to offer the legal framework for their operation and control ${ }^{15}$. However, the law enforced a maximum limit for advertising - no more than ten percent of total daily broadcasting time and no more than ten minutes per hour of programming; this legislation was later changed and completed to meet the EU requirements and regulations ${ }^{16}$. It was as late as 1998 that the Law 7 (1) was passed by the House of Parliament and Cyprus Radio-Television Authority was introduced, a regulatory body with wide powers and responsibilities regarding matters such as the establishment and operation of the private broadcasting sector ${ }^{17}$. In short, the introduction of private channels occurred in a vague and fairly deregulated environment, since the existing laws provided only the basic framework for licensing and operation whilst they proved insufficient to deal with more perplexed issues of commercial broadcasting ${ }^{18}$.

The first private station introduced in Cyprus was LOGOS and its main shareholder was the Cypriot Church (later on leased by private shareholders of the Greek TV station, MEGA, and renamed as MEGA Cyprus). After that, several others made their appearance ( $A N T 1$, etc.), either national and/or local. As free-to-air (FTA) terrestrial commercial television continued its growth, the first subscription-based TV station, Lumiere TV (LTV), began broadcasting in Cyprus in 1993 by means of an analogue terrestrial distribution system. Alfa TV, also a pay TV station, followed LTV ${ }^{19}$. Together LTV and Alfa set the scene for the pervasiveness of multi-channel, multi-platform pay television options in Cyprus (e.g., Primetel, Cytavision, Cablenet). In the FTA broadcasting landscape, in 1995, Sigma TV station - part of a larger vertically-integrated media organisation - began broadcasting to a national audience in Cyprus, thus becoming the third national commercial FTA station. Another commercial FTA television station, called CNC Plus, also began broadcasting in Cyprus in 2003, becoming the fourth commercial FTA station ${ }^{20}$.

As expected, the first professionals employed by the private television channels came from the public broadcasting organisation ${ }^{21}$. As a result, mentalities and practices of the past, e.g., regarding professional journalistic roles and/ or professional attitudes, remained evident in the country's private broadcasting sector; for example, the existing and historically established pattern of partisanship in the press was similarly adopted by private television entities indicating the close linkage between media and political institutions, with the media adequately responding to their watchdog and fourth estate roles in rare cases only 22 .

The Cypriot audiovisual environment was decisively altered after 2011, due to technological changes within the market, when digital terrestrial television was introduced. Since 2012, the Greek-Cypriot viewers have had the ability to watch audiovisual content in more than 250 channels (cable, satellite, traditional channels, etc. $)^{23}$. As expected, following the global trend in private broadcasting in pursue of high viewership ratings resulting in high advertising revenue $^{24}$, the Cypriot private TV channels became highly competitive in order to attract viewers: the majority of

\footnotetext{
14 Christoforos Cristoforou, 'Greek Cypriot media development and Politics', 2010, 235-245.

15 Chrysanthos Chrysanthou, Mass Media: Martyrs and lead actors, 2008, 144-145.

16 Andreas Sofocleous, Mass Media in Cyprus (in Greek), Nicocles Publishing House, 2008.

17 Source: http://www.crta.org.cy/default.asp?id=266

18 Cristoforos Christoforou, 'Greek Cypriot media development and Politics', 2010, 240.

19 Andreas Sofocleous, Mass Media in Cyprus, 2008.

20 Nicholas Nicholi, 'The role of Public Service Broadcasting in Cyprus during a Time of Austerity', $2014,210$.

21 Chrysanthos Chrysanthou, Mass Media: Martyrs and lead actors, 2008, 146-154.

22 Christoforos Christoforou, 'Greek Cypriot media development and Politics', 2010.

23 Theodora Maniou, Television, Society and Political News: A Theoretical and Empirical Approach to the Cypriot Public Sphere, $2013,73$.
}

24 Jean Seaton, 'Public, Private and mass media', in Stelios Papathanassopoulos, eds, The Mass Media in the 21st century (in Greek), Kastaniotis Publications, 2011, 251-265. 
Table 3. How does public opinion in Cyprus characterise news aired by TV channel?

\begin{tabular}{|c|c|c|}
\hline & Public Television & Private Television \\
\hline Neutral & $15 \%$ & $19 \%$ \\
\hline Objective & $22 \%$ & $12 \%$ \\
\hline Subjective & $16 \%$ & $22 \%$ \\
\hline Trustworthy & $14 \%$ & $13 \%$ \\
\hline Unreliable & $17 \%$ & $19 \%$ \\
\hline Insipid & $15 \%$ & $15 \%$ \\
\hline No opinion & $1 \%$ & $0.1 \%$ \\
\hline Total & $100 \%$ & $100 \%$ \\
\hline
\end{tabular}

programmes transmitted through private channels are entertainment productions such as reality shows, soap operas and sports with the exception of news broadcasting, which itself has added in its flow new elements that relate to the commercial model such as news regarding product launching and the lives of celebrities ${ }^{25}$. As Roussou points out, the meta-privatization TV productions can be described as expressive of the disjuncture in social continuity and the lack of cultural cohesion that accompanies contemporary Cypriot society. The intense rhythms of urbanization and the heterogeneity of city dwellers, the amalgam of lifestyles, rules of conduct and entertainment, all delineate today a Cypriot society caught in an encounter between late tradition and late modernity; it is a society moving away from the 'essentialism' of fixed discourses and poised or crystallized cultural identities, which reflects the social transition of the country from postcolonial to late modernity ${ }^{26}$.

Private television in Cyprus appeared in 1992 as a universal demand on behalf of the local public opinion, since (as previously mentioned) the public felt that news transmitted through $C y B C$ were biased in favour of the government in office ${ }^{27}$. However, very soon after the introduction of private TV channels, the same public realised these channels could not be trustworthy and reliable in terms of information dissemination, especially regarding political issues. In fact, a survey from 2010 in Cyprus shows that public opinion, after 18 years of co-existence for public and private television stations, tends to find public television more trustworthy and reliable than the private, as Table 3 indicates ${ }^{28}$.

Additionally, a study from 2015 in the news aired by the Cypriot television ${ }^{29}$ showed lack of balanced reference to the positions of all involved parties in the news, attribution of responsibility to one specific side, no inference to the deeper causes of conflict or to the possibilities of de-escalation and use of divisive language in the news. As a result, audience measurements in 2015 and 2016 in Cyprus $^{30}$ show that public opinion considers television as the less reliable medium.

However, historically, television, both public and private, used to be a highly influential medium in Cyprus, while most of the significant national events in the country's history took place via television ${ }^{31}$, as the following analysis will demonstrate.

25 Niki Menelaou and Theodora Maniou, 'Watching the News: Is a way out of the manipulation of Information and the construction of reality feasible?', International Journal of Business \& Social Sciences, 4, 3, March 2013, 137.

26 Naya Roussou, 'Research Note: Cypriot Television, Dialect Productions and Demotic Culture - Urbanization, Westernization or New Resistance Identities?', European Journal of Communication, 21, 1, 2006, 93.

27 Christoforos Christoforou, 'Greek Cypriot media development and Politics', 2010.

28 Theodora Maniou, Television, Society and Political News: A Theoretical and Empirical Approach to the Cypriot Public Sphere, 2013, 134-135.

29 Dimitra Milioni, Vaia Doudaki, Panagiotis Tsiliyiannis, Venetia Papa and Konstantinos Vadratsikas,'Conflict as News and News as Conflict: A Multidimensional Content Analysis of TV News in Cyprus', International Journal of Communication, 9, $2015,2408$.

30 Eurobarometer, Fall 2015 and Fall 2016 for Cyprus. Available at: http://ec.europa.eu/COMMFrontOffice/publicopinion/index.cfm/Survey/ getSurveyDetail/instruments/SPECIAL/surveyKy/2119

31 It has to be taken under consideration that this study reflects the situation in the broadcasting sector regarding the Republic of Cyprus and not the northern part of the country which remains under Turkish occupation. 
Table 4. Media Reliability in Cyprus.

\begin{tabular}{lcccc}
\hline & 2015 & & \multicolumn{2}{c}{2016} \\
\hline & Reliable & Not Reliable & Reliable & Not Reliable \\
Press & $31 \%$ & $59 \%$ & $39 \%$ & $46 \%$ \\
Radio & $40 \%$ & $52 \%$ & $53 \%$ & $37 \%$ \\
Television & $40 \%$ & $59 \%$ & $48 \%$ & $47 \%$ \\
Social Networks & $27 \%$ & $45 \%$ & $36 \%$ & $39 \%$ \\
\hline
\end{tabular}

\section{The Cypriot History through Television: Media Policy, Politics and Culture}

Globally, media policy has attracted attention with every historical, cultural and technological 'breakthrough'32, since, as the media sector has undergone significant developments throughout history, it has become the object of major re-regulation. Sarikakis identifies several major areas of discourses affecting re-regulation, with the most important ones being the changing societal attitude towards the role of the media as well as the relation between media and the marketplace ${ }^{33}$. In this perspective, the Greek-Cypriot broadcasting sector, and especially television, was largely affected by the historical and, subsequently, cultural and economic (market oriented) developments that took place within the country.

In fact, the Republic of Cyprus has had its share of political and economic crises since its origins in 1960, although most were linked to, especially after 1974, the country's main national political problem: the Turkish military occupation of northern Cyprus. The island was divided in 1974 following a coup against the President, which led to its invasion by Turkish military forces, the occupation of the northern part of the island and the splitting of the population with most Turkish-Cypriots in the north and Greek-Cypriots in the south ${ }^{34}$. During the coup on 15 July 1974 , the lives of President and Archbishop Makarios were endangered and information was leaked that the President was dead. However, Makarios managed to escape and his first act was to address the nation through the Free Broadcasting Station of Pafos (a city in the west of the island) and re-assure citizens he was alive and fighting for the sake of the country.

Video 1. Public address of President Makarios in 15 July 1974. Please visit the online version of the article to watch this video.

The events that took place in 1974 resulted in severe changes concerning the country's television landscape. First of all, although the country was divided between North and South, the Constitution of 1960 remained active and it has not been changed until today in the Republic of Cyprus. In this perspective, within the Republic, the only television station allowed to air (until 1992) was $C y B C$, while in the North the situation was completely different and citizens had - and still have - access to Turkish and local Turkish-Cypriot channels that started to operate within the next decades; the first one, established in 1976, was the state-owned television station BRT ${ }^{35}$. Although statistics regarding the ethnicity of the population in Cyprus have been a bit imprecise since 1974, at that time it was estimated that $85 \%$ of the population were of Greek-Cypriot origin, 12\% were Turkish-Cypriots, and the Armenian, Latin and other Catholic

32 Dwayne Winseck, 'Pursuing the Holy Grail: Information Highways and Media Reconvergence in Britain and Canada', European Journal of Communication, 13, 3, 1998, 337-74.

33 Katharine Sarikakis, Powers in Media Policy: The challenge of the European Parliament, Peter Lang, 2004, p.14.

34 Theodora Maniou and Irene Photiou, 'Watch-dog journalism or hush-puppy silencing? Framing the 2013 banking crisis in Cyprus through the press', Catalan Journal of Communication and Cultural Studies, 9, 1, Spring 2017, 43-66 (DOI: 10.1386/cjcs.9.1.43_1).

35 This study refers to the broadcasting sector in the Republic of Cyprus, and it is not in the immediate goal of the paper neither to analyse nor to present the media environment in the occupied area of Northern Cyprus. 
groups comprised the remaining $3 \%$ of the population ${ }^{36}$. In this perspective, CyBC offered (and still does) a wide variety of programmes in English and Turkish.

Video 2. News in Turkish on СyBC. Please visit the online version of the article to watch this video.

In terms of cultural aspects, this ongoing policy of $C y B C$ to present television programmes in both Greek and Turkish - although several times debated, both for and against - seems to be closely related to the national political problem of the country. This is why although the organisation faces severe economic difficulties, since it is directly depending on the Parliament for funding allocation, funds concerning the production of Turkish programmes were not only confiscated but, on the contrary, they reach as high as 429,000 euros (formal figures concerning the year 2015) $)^{37}$.

The Greek-Cypriot community is frequently affected by the social, political and economic changes in Greece, due to their affiliation with the Greek language and their shared history and religion. In this perspective, $C y B C$ often cooperates with $E R T$, the Greek Broadcasting Corporation, either in terms of programme exchange or in terms of joint initiatives.

Video 3. The first joined broadcasting programme of ERT and CyBC (1990). Please visit the online version of the article to watch this video.

Additionally, ERT has been allowed to air its programme in Cyprus independently, while the programme of Greek private television channels is accessible, either through subscription TV platforms or via synergies with Cypriot private channels. After the introduction of private television channels, most of them incorporated in their programmes Greek productions (mostly sitcoms and shows), although Greek-Cypriot productions seem to be far more popular than the Greek ones ${ }^{38}$.

There were two key-point events that marked the country's recent history. In the early months of 2004, there was a great public debate concerning the forthcoming referendum for the resolution of the Cyprus problem under the auspices of the ANAN plan and the country's accession to the EU. President Tassos Papadopoulos addressed the citizens through $C y B C$ in order to urge them to vote against the $A N A N$ plan.

Video 4. Tassos Papadopooulos' public address for the ANAN plan in April 2004. Please visit the online version of the article to watch this video.

Following the referendum that led to the denouncing of the ANAN plan, Cyprus became a member of the EU in May 2004 and from then on, the Greek-Cypriot broadcasting sector adjusted its performance in the EU's regulations. The digitization process of the Greek-Cypriot audiovisual landscape began immediately after the country's accession to the EU in 2004 under the auspices of various governmental departments in order to meet the EU deadlines for analogue switch-off and, in this perspective, deal with issues such as frequency allocation and multiplex ownership of private television stations ${ }^{39}$. At last, Cyprus introduced digital terrestrial television in 2011, after a long and turbulent period of negotiations between the affected counterparts.

Finally, in March 2013, following the wider economic crisis that hit the countries mainly in the European south, Cyprus experienced the consequences of an unprecedented banking crisis that led, among other, to the haircut on bank

36 Theodora Maniou, Irene Photiou and Elena Ketteni, 'Mediating patriotism and triumph through the national press: Newspaper content and journalistic perceptions', International Journal of Social Science Studies, 4, 6, 2016, 65-76 (DOI:10.11114/ijsss.v4i6.1588).

37 'Turkish Programmes in RIK' (in Greek), Fileleftheros, 9 May 2017, http://www.philenews.com/eidiseis/paraskinio/article/396963/oitoyrkikes-ekpompes-toy-rik

38 Myria Vassiliadou, 'The Cypriot Landscape', in Georgios Terzis, eds, European Media Governance: National and Regional Dimensions, Intellect, 2007, 201-213.

39 Nicholas Nicholi, 'Digital Television in Cyprus', in Wendy van der Broeck \& Jo Pierson, eds, Digital Television in Europe, VUBPress, $2008,33-42$. 
deposits above 100,000 euro. President Nikos Anastasiades addressed the nation through CyBC, in an effort to explain the measures imposed by the EU institutions and IMF upon Cyprus.

Video 5. Nikos Anastasiades' public address for the banking crisis in March 2013. Please visit the online version of the article to watch this video.

The Greek-Cypriot broadcasting sector was immediately affected by this unprecedented crisis: $C y B C$ suffered significant loss of its governmental subsidy while market failure resulted in the loss of advertising revenues ${ }^{40}$. At the same time, this loss of advertising revenues had a huge impact upon the private broadcasting sector: as a result television channels decreased their workforce while internal production programmes were limited and/or cut back.

\section{Conclusion}

As this analysis has shown, television in Cyprus was introduced under notably assertive criteria, those of the BBC, while all the important historical events in the country's short independent history were connected, one way or another, to the historical evolution of television. In recent years, $C y B C$ has also been able to adapt fairly well to the EU regulatory environment; the Cyprus Broadcasting Act and its amendment in 2013 is aligned with the EU's major media law, the Audiovisual Media Services Directive (2010/13/EU) ${ }^{41}$. However, from 2013 and onward, CyBC's position has become even more precarious due to the austerity measures imposed. Additionally, the medium of television failed to develop independent modes and structures from the governments in office and, in this perspective, it historically reflected the vulnerabilities of the country's political system, which kept it underdeveloped and confined for a long period of time.

And while this may seem expected for the Cypriot PSB, considering the broader broadcasting pattern for the development of PSB television channels in South Eastern Europe, it comes as a surprise that the same pattern was followed for the development of the private broadcasting sector. The privatisation period for the Cypriot television started in 1992 and, even then, television channels failed to deploy contemporary broadcasting characteristics and neglected to adopt up to date audiovisual policies, as this study has shown. Additionally, following the global trend after the 1980s, although television channels multiplied, diversity of 'voices' seems to have declined, since private channels were introduced and developed under the already existing media conglomerates, groups and companies within the auspices of the same media owners ${ }^{42}$.

Focussed on the period after 2000, this work highlighted the specific characteristics of the current private broadcasting sector in the country, through a comparative study of different surveys (conducted in 2010, 2015 and 2016), depicting both the audience point of views and the news content of private television channels. As this study has shown, the private broadcasting sector suffers a series of demerits that seem to affect its development, either in terms of technological evolution or in terms of market expansion; the vague and fairly deregulated environment especially in the early days of private broadcasting, partisanship in both journalistic professional attitudes and media owners' policies and the delay in adopting EU directives regarding technological, market and regulation amendments seem to be the most distinctive ones.

All of these vulnerabilities appear to be closely linked to the direct and/or indirect relationship between broadcasting and politics that historically prevails from the Republic, the country's national problem - which occurred after the

40 Nicholas Nicholi, 'The role of Public Service Broadcasting in Cyprus during a Time of Austerity', 2014.

41 Ibid., 210-211.

42 James Shanahan and Michael Morgan, Television and its Viewers (in Greek), Polytropon Publications, 2006, 411. 
Turkish military invasion in 1974 - up to individual matters regarding internal issues, governmental policies and/or other political initiatives. As a result, the Cypriot public tends to perceive television, even today, as an untrustworthy and unreliable medium, linked to either private, commercial or governmental interests. In fact, the comparative measurements regarding recent years show that the public tends to perceive public television more trustworthy and reliable than the private, although television in general is characterised as the least reliable medium.

Added to all these, the recent austerity situation, evident mainly after 2013 when the 'haircut' of bank deposits and the imposition of financial measures took place in Cyprus, the future of the private broadcasting sector in the country seems - at least at this point - quite uncertain. A shed of 'light' in the blurred audiovisual market brought the introduction in Cyprus of ALPHA TV in 2016, a private TV channel operating as a syndicate of its Greek counterpart, since its start-up showed that the Cypriot audiovisual market can afford more entities, which can raise competition in terms of content and advertising revenue.

However, Cypriot television channels still have a long road ahead in order to reach their European colleagues and join the new, digital era of broadcasting $2.0 \ldots$

\section{Biography}

Dr. Theodora Maniou is a Lecturer in the Department of Journalism, Frederick University, Cyprus. She holds a BA in Journalism (School of Journalism \& Mass Media, Aristotle University of Thessaloniki, Greece), an MA in Communication's Policy Studies (CITY, University of London, UK) and a PhD in Journalism (School of Journalism \& Mass Media, Aristotle University of Thessaloniki, Greece). Her area of specialization focuses on Print, Electronic and Online Journalism and Mass Media. She is a regular member of the Journalistic Union of Macedonia-Thrace (Greece), the European Federation of Journalists and the International Federation of Journalists. 